\title{
Developing a problem-based local history module to improve the critical thinking ability of senior high school students
}

\author{
${ }^{* 1}$ Novita Mujiyati; ${ }^{2}$ Warto; ${ }^{3}$ Leo Agung Sutimin \\ ${ }^{1}$ Graduate School of Universitas Sebelas Maret \\ J1. Ir. Sutami 36 A, Kota Surakarta, Jawa Tengah 57126, Indonesia \\ ${ }^{2}$ Faculty of Cultural Sciences, Universitas Sebelas Maret \\ J1. Ir. Sutami No. 36A, Jebres, Kota Surakarta, Jawa Tengah 57126, Indonesia \\ ${ }^{3}$ Faculty of Teacher Training and Education, Universitas Sebelas Maret \\ J1. Ir. Sutami No. 36A, Jebres, Kota Surakarta, Jawa Tengah 57126, Indonesia \\ ${ }^{*}$ Corresponding Author. E-mail: novitamujiyati2@gmail.com \\ Submitted: 15 March 2017 | Revised: 11 April 2018 | Accepted: 06 May 2019
}

\begin{abstract}
This research aims at developing a problem-based local history module as learning media to improve the critical thinking ability of Senior High School students. This research employed a research and development (R\&D) method referring to ADDIE development design. The procedure of designing ADDIE development included (1) analyzing to identify the learning media needed, (2) designing to organize the material of module corresponding to basic competency and indicator, (3) developing to obtain the finished product of module through validation and limited and large-scale trials, (4) implementing the module during learning process, and (5) evaluating to find out the effectiveness of module. The results of the research show that the problem-based local history module effectively improves the students' critical thinking ability. Through this module, the students are directed to understand a variety of aspects affecting a problem and relating it to the knowledge owned. The problems organized in the module are contemporary and related to the student environment. The process of connecting new knowledge to preexisting knowledge enables the students to develop their own knowledge and to improve their critical thinking ability in solving the problems.
\end{abstract}

Keywords: module development, problem-based local history, critical tbinking

Permalink/DOI: https://doi.org/10.21831/reid.v5i1.13334

\section{Introduction}

History learning at senior high school contributes to improving the cognitive, affective, and psychomotor abilities of students. Kochhar (2008, pp. 54-64) suggests that the values found in history learning are (1) scientific, (2) informative, (3) ethical, and (4) nationalism values. Meanwhile, according to Aman (2011, p. 57), History subject plays a strategic role in creating the nation's disposition and prestigious civilization, and in creating Indonesians who have nationalism and love to the homeland. History is the subject instilling knowledge, attitude, and values con- cerning the change and development process of Indonesian and world people from the past to the present (Sutimin \& Wahyuni, 2013, pp. $55-57)$.

Thus, history learning is not only limited to knowledge or memory about many events which have occurred. History learning should enhance the students' critical thinking ability concerning the change, the development, and also the interrelationship between events. In addition, the students who have ever learned history should have a wise attitude and understand their identity. In the learning process, the teacher is the learning designer aiming to make the change toward 
the better one and the mastery of particular skill within the students. The interaction between teachers and students and environment condition should be designed to encourage the students to understand and to respond critically to what they are learning. As Illeris (2011, pp. 9-24) suggests, learning is a broad process that should pay attention to internal and external condition of students, so that functionality, sensibility, and also sociality constituting the competency of students will be created.

Considering the results of preliminary study, history learning at senior high schools has not arrived yet at the stage of improving the students' cognitive domain, particularly critical thinking ability. Supriatna (2011) says that history learning so far is dominated by collective memory so that the construction of history learning is required through contemporary issues discussed using historical perspectives. The discussion of the contemporary problems using historical perspective enables the students to construct their own knowledge and to think critically because it gives direct experience and involves the students' analysis process. Meanwhile, if the learning activity is dominated with collec-tive memory, such the process has not been stated as learning. It is because an action can be said as learning if it includes three criteria: (1) involving the change, (2) lasting for a long time, (3) occurring through experience (Schunk, 2012, pp. 5-6). Meanwhile, the construction of contemporary issues-oriented history learning proposed by Supriatna theoretically indeed yields the meaningful learning activity. It is because the students involved actively in the analysis process will construct their own knowledge and think critically.

However, it is noteworthy that contemporary issues-oriented learning will not construct the students' knowledge and improve their critical thinking ability if it is not designed and supported with appropriate learning media. Masek and Yamin (2011) suggest that theoretically, problem-based learning can improve critical thinking ability. However, empirically, improving students' critical thinking ability through problem-based learning takes time and is affected by such factors as age background, students' achievement, learning design, and media support. Therefore, to achieve the objective in applying problembased learning, the attention should be paid to facilitators' role and learning media.

Considering the aforementioned phenomena, this research aims at developing learning media in the form of problem-based local history module and module using strategy in the learning process. Meanwhile, the objective of learning process using problembased local history module is to improve the students' critical thinking ability, because in the history learning process, the role of media, particularly module concerning the local history and module using strategy, is very desirable. Module, according to Daryanto (2013, p. 9) is one of the teaching materials packaged comprehensively and systematically, containing a series of learning experiences planned and designed to help the students master the learning objectives specifically.

It means that a module can be used any time by the students and not always dependent on the teachers' role. However, the use of the module in the learning process should consider the appropriate learning method and strategy. Thus, the module containing local history materials and applying contemporary issues will effectively practice the students' critical thinking ability in the learning process if it is applied using an appropriate strategy. Meanwhile, when the module is used to learn independently, it will facilitate the students in understanding materials and also constructing their understanding because it has contained problem solving instruction. The contemporary issues existing in the module allow the students to conduct analysis based on historical perspectivesin order to improve their critical thinking ability.

\section{Method}

This research employed a research and development $(\mathrm{R} \& \mathrm{D})$ referring to ADDIE development design. ADDIE, according to Suranto (2015, p. 154), is a model and design to create a learning product or a design to implement a program. Furthermore, according to Pribadi (2014, p. 23), ADDIE design includes five stages of activity: analysis, (2) de- 
sign (3) development (4) implementation, and (5) evaluation.

The research subject was 150 students of Class X1 at SMAN 1 Trimurjo. The subject was chosen by purposive sampling technique. The data collecting techniques in this research were observation, interview, document analysis, and questionnaire. Observation was conducted to know the history learning process at SMAN 1 Trimurjo. Then, an interview with history teacher and students about the obstacles during the history learning process was conducted. The interview result shows the lack of local history module at SMA Negeri 1 Trimurjo. In order to follow up the problem, document analysis was done in the form of learning tools and document analysis for the development of local history module. After the module has been prepared and used in the learning process, the questionnaires were conducted to the teacher and students about the effectiveness of the module.

The processing and analysis techniques of the preliminary data (pre-survey) gained through observation and interviews were measured using qualitative methods. The process of document analysis in the form of learning tools and module development was obtained through literature study; then the development results were validated by the material experts and media experts through questionnaires. From the description of the questionnaire, the module was revised and tested. For the implementation phase of the module, the data obtained were analyzed quantitatively through T-test. In analyzing the quantitative results, the SPSS program was employed in this study.

\section{Findings and Discussion}

\section{Learning Media Use}

Based on the results of pre-survey in SMA Negeri Trimurjo, through both observation and interview with History Subject teachers and students, it can be seen that the use of textbook supporting media such as module is still minimal. The results of observation on the learning process indicate that the media, such as local history module has not been used yet. Meanwhile, the result of the interview with teacher and students shows that the understanding on local history is still very inadequate, even the teachers state that in the learning process so far, the discussion about local history is still very inadequate. It is because of limited learning sources and teaching materials addressing the local history.

The lack of history learning media cannot be ignored, because it is one source of information in the learning process. Rosyad (2003, p. 120) says that, methodologically, learning media aims (1) to help explain the subject matter the teacher delivers, (2) to help the students in learning activity, (3) to help the teacher dealing with space and time, (4) to give real experience to the students. Learning media is an instrument for delivering the teaching messages (Arsyad, 2010, p. 3). The types of learning media include: (1) audio using the role of sound in delivering the learning, (2) visual is the media using visual sense such as silent movie, photograph, picture, chart, map, and the similar, (3) audiovisual is the media using sound and picture elements (Anitah, 2010, pp. 7-69).

Concerning the arguments above, it can be seen that media is very desirable in the learning process; for that reason, the development of learning media should take the students' need and learning environment into account. Learning media serves to deliver information to the students concerning the essence of learning. Without media use, the learning will not attract the students' interest and will not motivate the students to understand the information delivered. Meanwhile, regarding the compatibility of media to the students' need and learning environment such as infrastructure and affordability aspect, the media developed should be used flexibly. It is because not all schools have adequate infrastructure to apply a variety of media. Considering this fact, the type of media developed in this research is visual media in the form of a problem-based local historical module to improve the students' critical thinking ability. Simply, the function of media in learning process is represented in Figure 1. 


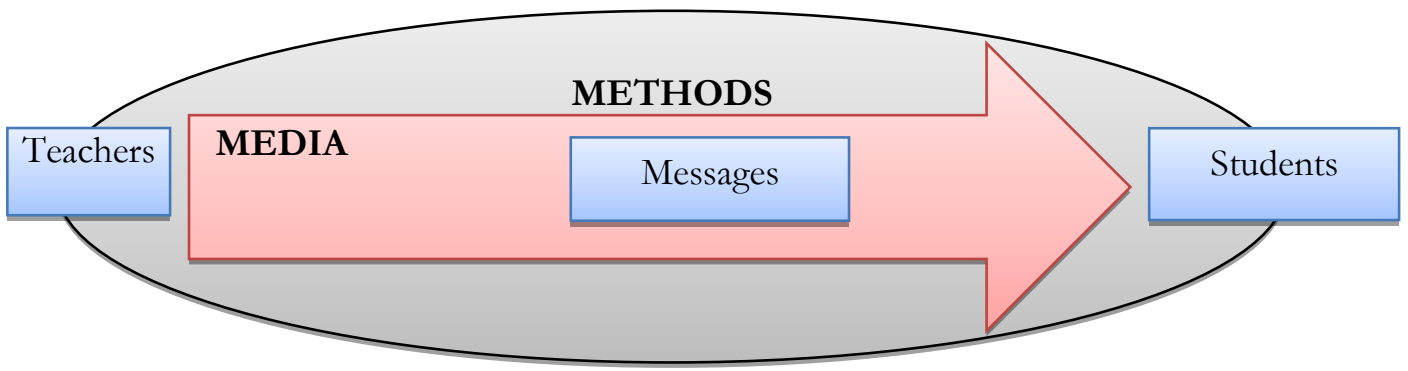

Figure 1. The function of media in learning process

Furthermore, local history is made the material in the module because it is the events familiar to and understandable to the students to create their knowledge. Wasino $(2005$, p. 1) says that historical learning should begin with the historical fact which is close (familiar) to the environment where the students live, and then the fact far away from the students' residence. Local history enables us to have an intimate relationship to the very local events which are not likely considered so far, but they are actually playing an important and valuable role in creating larger events (Abdullah, 1990, p. 19). Meanwhile, according to Aktekin (2010, pp. 86-105), historical learning utilizing local events will enrich knowledge and creates the students' identity.

Through local history, the students will feel learning about their own life. Something closely related to the students, despite smallness, will be more attractive than everything big but having no relationship. Also, in using the module, the appropriate strategy should be chosen to motivate them in finding and analyzing the source to find a resolution to the problems. The proper strategy in learning using the module is to use problem-based learning (PBL) in a group. Gallagher, et al., in Ward and Lee (2002, p. 17) say that Problem based Learning is the learning process, the learning starting point of which is based on the problem in real life. Thus, PBL will highly support the achievement of students' critical thinking ability.

Design of Problem-Based Local History Module

The design of module development is the process of organizing the problem-based local history material and adjusting the materi- al with Basic Competency and Indicator. The local history material organized is the History of Lampung people's resistance in the 19th century. The Lampung people's resistance in the 19th century, according to the 2nd book of Lampung Province's Daily Council - Batch 45 (1995, pp. 84-94), occurred several times led by Raden Intan I (1808-1828), Raden Imba II (1828-1834), Bathin Mangunang (1817-1834), and Raden Intan II (1850-1856). Such resistance shows the social solidarity bond among Lampung people with different clans when dealing with the Dutch. The values of solidarity bond include the cooperation of many clans based on the feeling of responsibility, tolerance, and voluntariness to sacrifice in terms of material, effort, and also mind, for the sake of struggle.

Through analyzing the social solidarity values in the resistance of Lampung people in the 19th century, the students will be directed to find the resolution to some problems currently occurring in Lampung. The problem in Lampung is interethnic conflict due to the poor interaction between Lampung people and the incomers so that the social solidarity between the communities is not established. Meanwhile, the native Lampung people currently become more jostled in their own area. The problem of conflict in Lampung, according to Humaedi (2014, pp. 148-162) is derived from a narrow interaction due to inadequate common space leading to the failed cultural acculturation and the religion issue worsening the condition in Lampung. From this study, it can be found that poor social interaction leads to uncreated social solidarity between communities. Thus, there was no care, solidarity, common responsibility, and feeling of shared interest and fate. 
It is the resolution obtained from historical analysis on the importance of social solidarity to Lampung people in the present that will be designed in the module. It is because to obtain the resolution, the students should understand their social environment and conduct historical analysis to recognize the values existing in Lampung people in the 19th century not existing in the present. Thus, through this understanding, the students can construct their knowledge and think critically. The compatibility of historical material concerning the Lampung people's Resistance in the 19th century to Basic Competency and indicator is presented in Table 1.

Table 1 shows that the material of Lampung people's resistance history in the 19th century will be included into the basic competency of the Indonesian Resistance Strategy against Western Colonialism before the 20th century and into the indicator of the Indonesian Struggle in many areas in fighting against Western Colonialism and Imperialism in Indonesia during the 20th century. The materials of Lampung people's resistance history in the 19th century which has not existed yet in the history textbooks will complement the students' knowledge to make them know that in their area, there had been a similar resistance with the other areas of Indonesia. The students' understanding of the Lampung people's resistance in the 19th century will facilitate the students to understand the resistance pattern in another area. In addition, the students will obtain a general description of people's resistance strategy before the 20th century more easily so that the basic competency and indicator of the learning can be achieved.
The Development of a Problem-Based Local History Module

The development stage is the process of validating the initial draft of problem-based local history module by material and media expert, and limited and large-scale tryout with the students taken randomly to obtain the final draft module to be implemented in the learning process. A validator is selected based on the compatibility of expertise to the media to be validated. If the media to be validated is a problem-based local history module, the validator will be the one with media and material expertise concerning local history. Thus, the validators selected in this research were two media experts and two material experts. The initial draft module to be validated is presented in Table 2.

The result of the validator assessment of the initial draft on the title is (1) Material Expert I assesses with an average score of 4.34 the value is included in the 'good' category. The aspects assessed by the Material Expert I include the material feasibility, linguistic aspects, aspects of presentation, module effects on learning strategies and aspects of the overall look. (2) Material Expert II provides an assessment with an average score of 4.14, with a good category. The aspects assessed by the Material Expert II are the same as those assessed by the Material Expert I. This is conducted to provide a comparison of opinion between the two Experts of Materials to obtain information about the module material that is completely valid. (3) Media Expert I gives an overall average score of 4.54, which belongs to a very good category. (4) Media Expert II gives an average score of 4.5, which is also included in the category of very good.

Table 1. The compatibility of history material concerning the Lampung people's resistance in the $19^{\text {th }}$ century to basic competency and indicator

\begin{tabular}{cc}
\hline Local History Material & \multicolumn{1}{c}{ History of Lampung People's Resistance in the 19th Century } \\
\hline Basic Competency & $\begin{array}{l}\text { Analyzing the Indonesian Resistance Strategy against Western Colonialism before } \\
\text { the } 20^{\text {th }} \text { century. }\end{array}$ \\
Indicators & $\begin{array}{l}\text { 1. Explaining the western Colonialism and Imperialism process in Indonesia. } \\
\text { 2. Explaining the impact of western Colonialism and Imperialism on Indonesia. } \\
\text { 3. Analyzing the Indonesian struggle in many areas in fighting against Western } \\
\text { Colonialism and Imperialism in Indonesia during the } 20^{\text {th }} \text { century. }\end{array}$
\end{tabular}


Table 2. The initial draft module to be validated

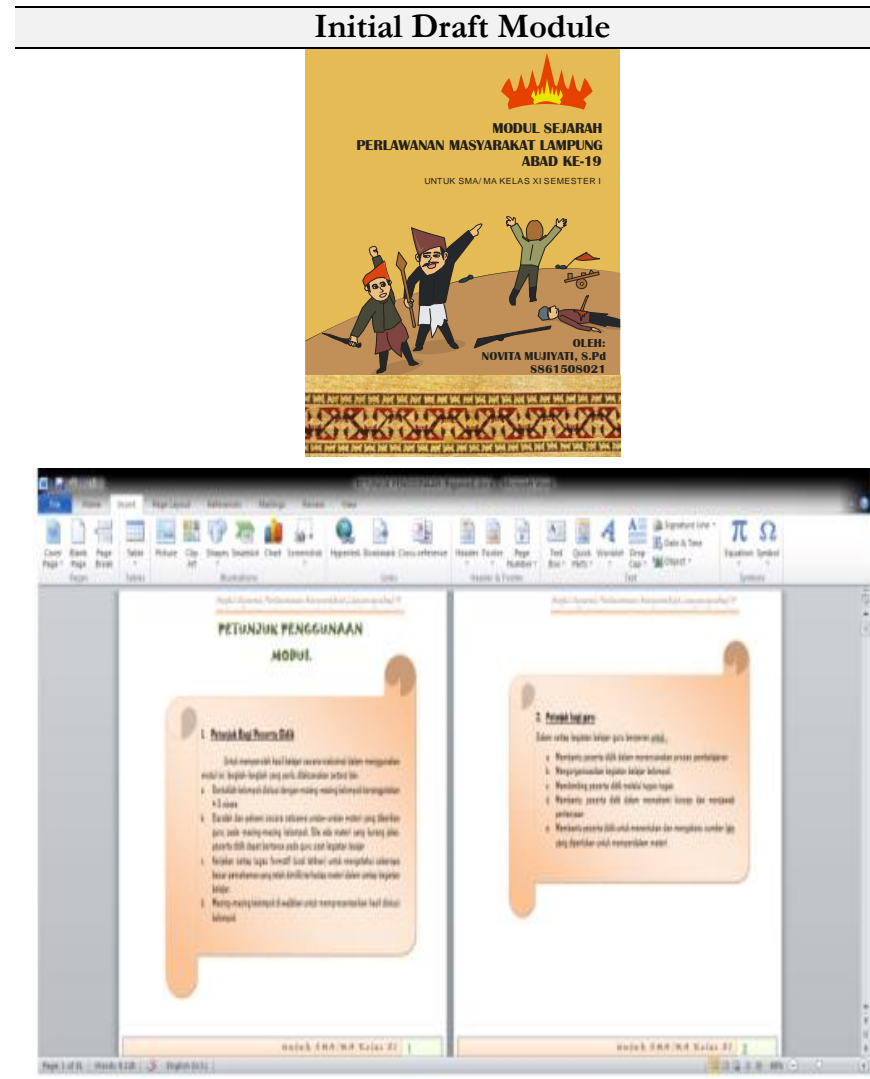

Cover of module

Note

Module manual for teachers and students.

Standard Competency, Basic Competency, and indicators, as well as learning objectives and benefits

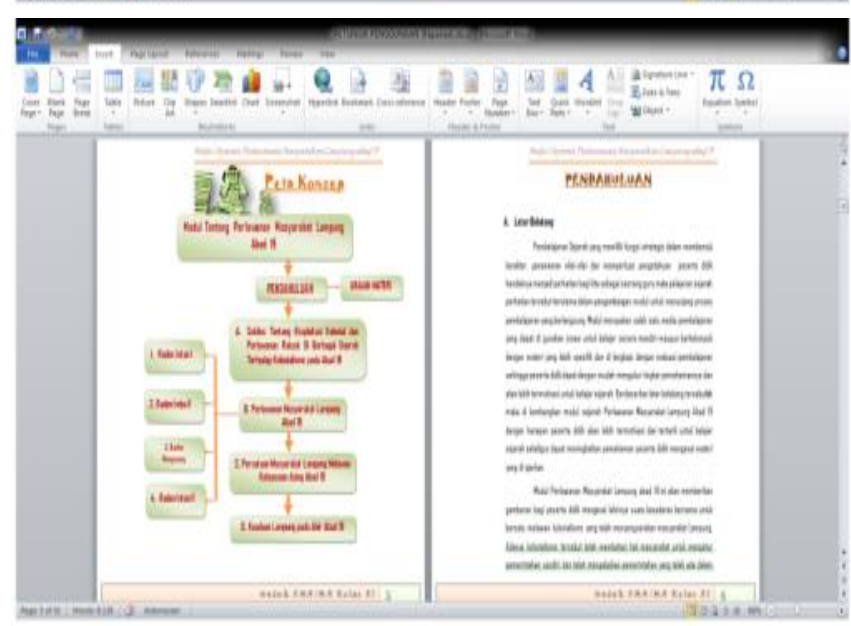

Concept Map, Introduction, and Material

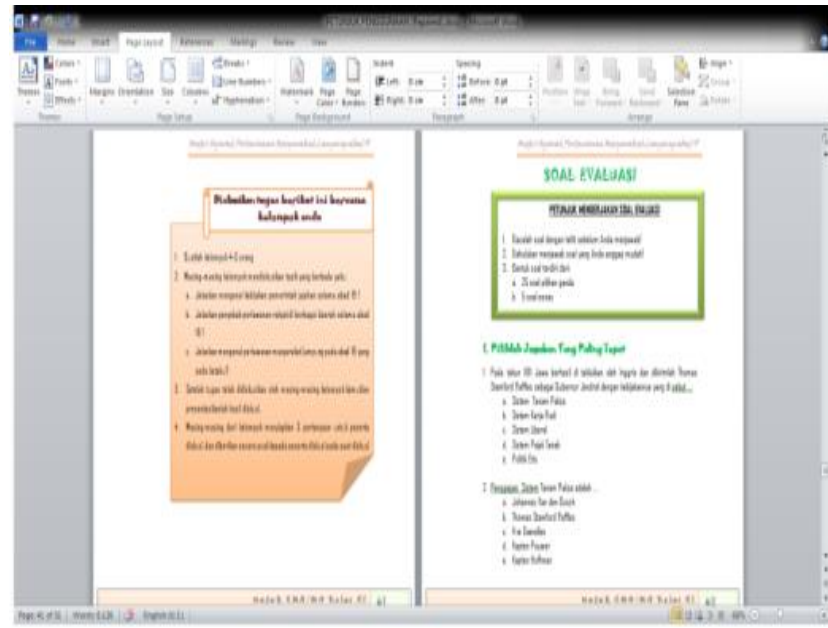

Summary, Evaluation Item and References 
The aspects assessed by Media Expert I and Media Expert II are presentation aspects of including the attractiveness of the drawing, page design, cover design, font type, color selection, inter-page transition sustainability, as well as legibility. From these assessments, the local problembased historical module can be used for further tests with revisions according to the validator's suggestion.

The revisions that need to be done in the module are as follows: (1) The first suggestion from Media Expert I is that the module developed should use a learning model and show model steps. The second suggestion is a compiled module that must be aligned with the module-making guidelines. Besides, the selection of the colors used in the module should be more considered. Considering that the module users are all students, the colors used should also be general. (2) Media Expert II gives suggestions concerning the timing of implementation. According to Media Expert II, the module of Lampung people's resistance in the 19th century based on problembased learning (PBL) would be better if it is implemented in two or three meetings, so that the historical values in the module can be comprehensively understood by the learners. (3) Material Expert I comments the number of years that do not yet exist, other than that the writing of the material must be based on a common event before heading to a more specific event of the 19th century Lampung society's resistance. (4) Material Expert II gives suggestions on the language use in the module which should be more communicative.

After the problem-based local history module has been improved based on the validators' suggestions, the next step is conducting a limited trial and extensive testing. The limited trial in this study includes two stages: a small group trial and large group trial. The result of the small group trial is a well-developed module with an average score of 4.2. From the small group trial process, the module was improved based on the advice from the students, as for the student's suggestion is that the writing on the module needs to be simplified to make it easier to understand. In addition, the tasks assigned in the module are too numerous, so that it needs to be reduced.
After the module is revised according to the suggestions, then, the large group trial was conducted. The result of the large-group trial is that the module was developed well with the mean score of 4.2 and stated as belonging to a good category with revision and ready to be used in a broad trial/tryout. In the broad tryout, the total score of 4.4 is obtained, belonging to a good category without revision. Thus, considering the assessment and approval from the history teacher for the 11th graders, the final draft module is obtained and stated as feasible to be used in the implementation stage. The final draft of problem-based local history module is presented in Table 3.

The Implementation of Module to Improve the Students' Critical Thinking Ability

The module implementation stage in the learning process is conducted in an experimental class through group work with problem-based learning (PBL) model. The PBL model, according to Barrow (in Huda, 2014, p. 71), is the one obtained through the process toward the understanding of a problem's resolution. The PBL model combines some disciplines in solving the problem (Anitah, 2009, p. 70). The learning can create highorder thinking ability and improve students' critical thinking ability (Sani, 2015, p. 127).

The module application using problembased learning (PBL) model in a group will lead the students to construct the meaning of the learning process and to improve their critical thinking ability in solving the problem. In history learning, the problem-solving process is used to interpret, evaluate, and criticize historical document (Gredler, 2011, p. 308). In interpreting, evaluating, and criticizing processes, the students are required to have many analyzed sources to support an argument. It is in this process that the students' critical thinking ability is constructed. Slavin (2011) states that the teaching of critically thinking ability can be effective when the learning process emphasizes on the reason for an argument rather than on the correct answer. In addition, there is a process of connecting to the common topic to the students, so that various perspectives will be obtained allowing for the free discussion between students. 
Table 3. The final draft of problem-based local history module

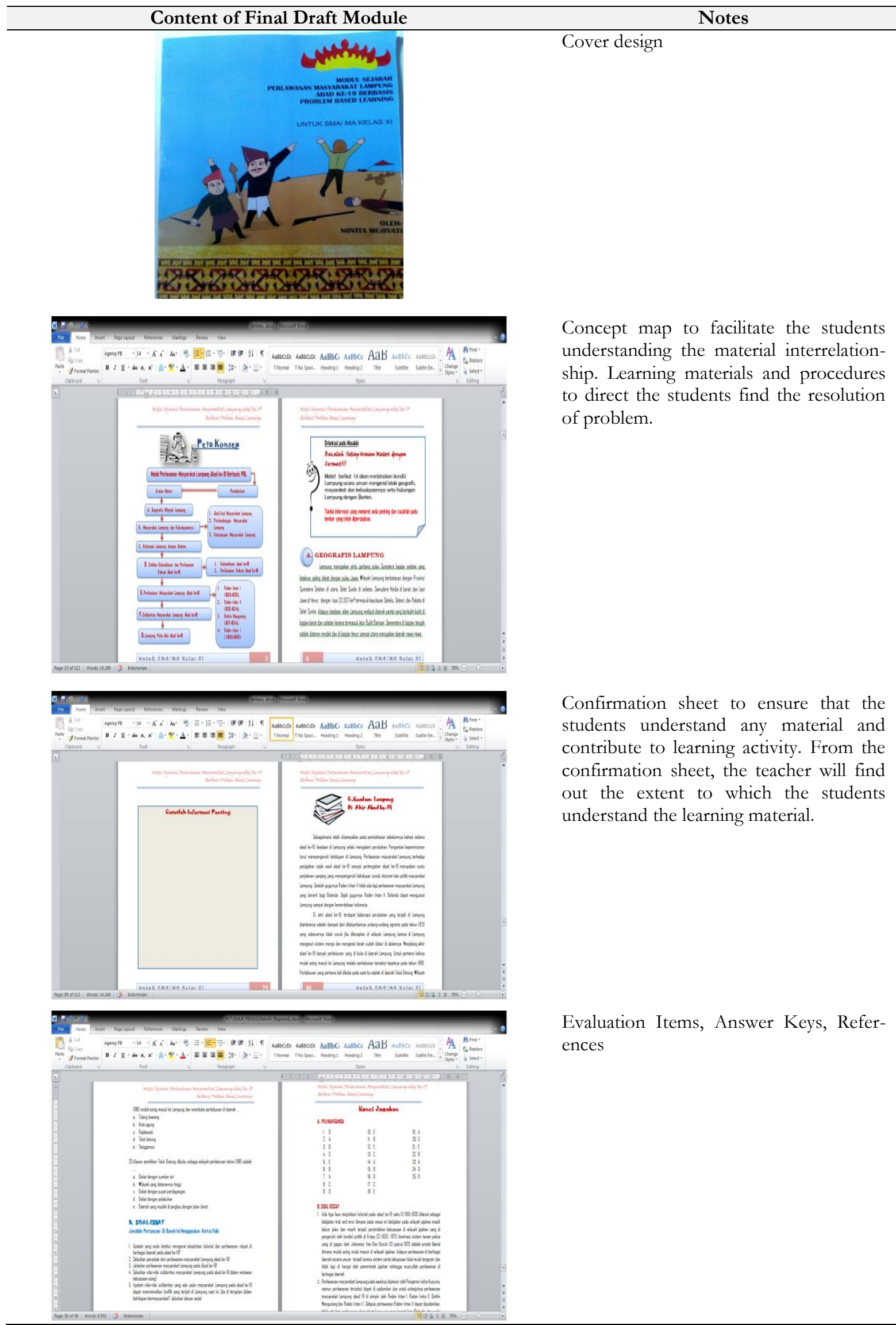


From the explanation, it can be seen clearly that the problem-based local history is the supplementary textbooks, supporting the students to explore their knowledge. The students will understand more easily the relationship between events from the narrow to the broader scopes. Meanwhile, the discussion process in finding the solution to the problem in the module leads the students to enter into the zone of proximal development (ZPD). Zone of proximal development (ZPD), according to Rezaee and Azizi (2012, pp. 5157), can be achieved when there is a gap between the students' ability and the knowledge level achieved. In this stage, teachers should conduct scaffolding and discussion activity with their group to achieve the students' critical thinking ability maximally to solve the problems. The procedures for designing the discussion activity in the problem-based learning model are presented in Figure 2.

The effectiveness of problem-based local historical module can be seen through the comparison of pretest and posttest result of evaluation in control class and experiment class. Before the treatment, the two classes had approximately the same average value of 64, while after the treatment (learning using modules), the experimental class using the module got a higher value of 82 . Meanwhile, the control class that did not use the module got the value of 70 . The effectiveness test on the module was conducted in the 11th grade of Social Science 2 as the experiment class and the 11th Grade of Social Science 3 as the control class in SMA Negeri 1 Trimurjo. The test conducted in the two classes includes learning achievement test and questionnaire for students' social solidarity. Next, the result of the test was calculated in SPSS 21.

Considering the result of the data processed in SPSS 21, it is found that the normality test shows that the two classes obtain significant value $>0.05$, meaning that they are distributed normally. The result of effectiveness test on the students' critical thinking ability shows the $\mathrm{F}$ value $=0.084$ at the significance level of $0.773>0.05$ so that there is a variance equation. Meanwhile, the result of $t-$ test shows that tstatistic $\neg$ value of 3.303 is at the significance level of $0.001<0.05$ so that $\mathrm{H}_{0}$ is not supported, the mean score of experiment and control classes is not the same after the treatment. There is a positive significant increase in critical thinking ability in the class using a problem-based local history module.

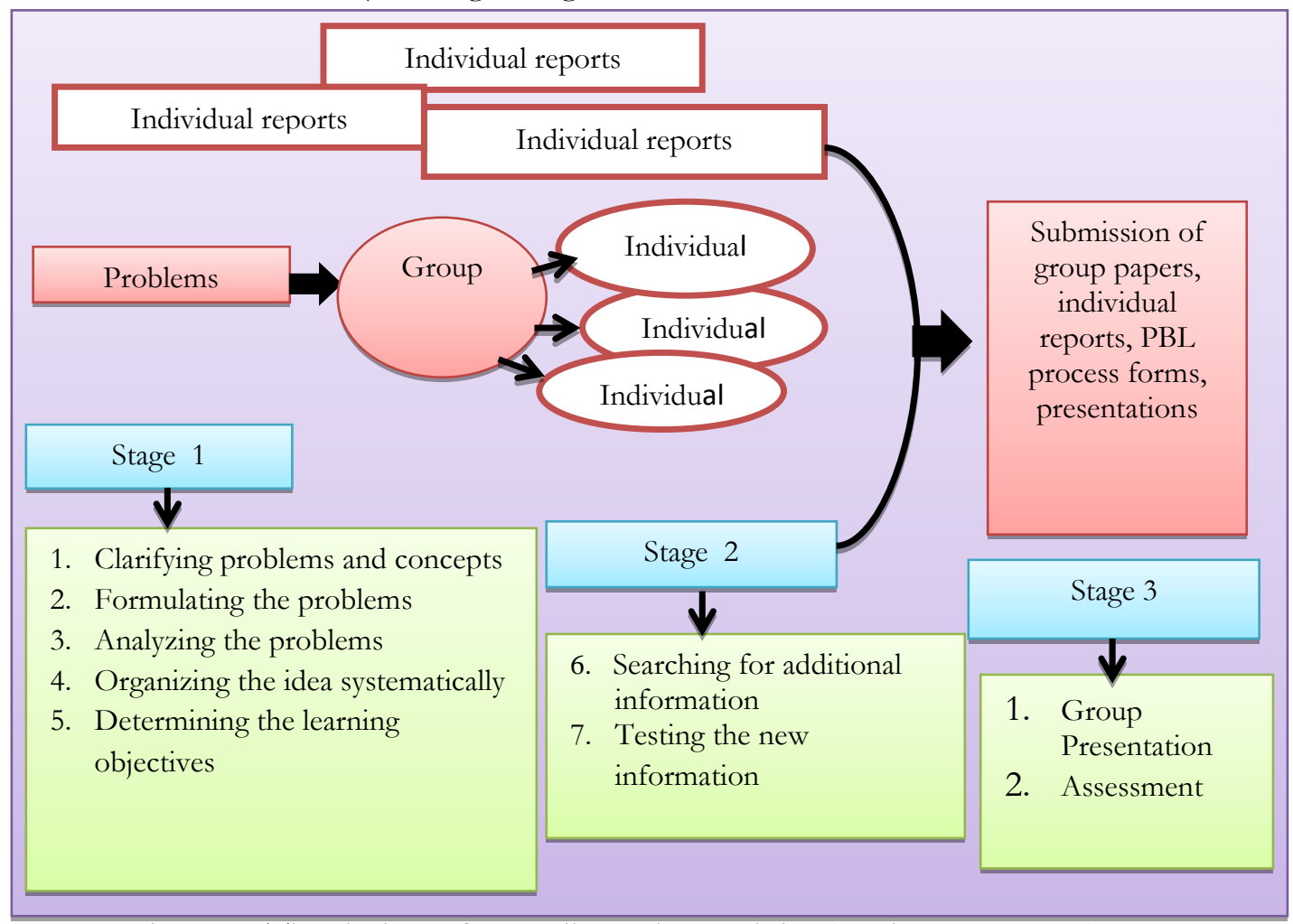

Figure 2. The design of PBL discussion activity (Amir, 2015, p. 27) 
The result of the research is relevant to the finding of research conducted by Suarsana and Mahayukti (2013) on the development of problem solving-oriented e-module. This study found that (1) e-module developed is high in quality, but still needs improvement, (2) the use of e-module can improve the students' critical thinking skill, and (c) the students' respond to e-module use in lecturing is very positive. Furthermore, Styron (2014) suggests that in-group learning using the problembased learning model effectively improve the students' critical thinking ability. The learning approach with critical thinking and building students' knowledge considerably contribute to the improvement of the students' achievement (Lunenburg, 2011, pp. 1-8). Considering some relevant studies in this research, and based on the effectiveness test conducted, it can be seen that the problem-based local history module effectively improves the students' critical thinking ability.

\section{Conclusion}

The development of problem-based local historical module using ADDIE design and applied through a problem-based learning model can effectively improve the students' critical thinking ability. Through such model, the students understand in-depth the relationship between events and expand their understanding of historical analysis to find the resolution to social problems existing in the students' environment. In addition, this research proves that the development of problembased local historical module can be used as the supplement learning source for textbook.

This research shows that the effectiveness of the learning process is not only based on the learning model applied by the teacher. Meanwhile, the availability of teaching materials in the form of local-history modules that apply a problem-based learning model also becomes support in improving student's skills in critical thinking.

\section{References}

Abdullah, T. (1990). Sejarah lokal di Indonesia. Yogyakarta: Gajah Mada University Press.
Aktekin, S. (2010). The place and importance of local history in the secondary history education. Journal of Theory and Practice in Education, 6(1), 86-105.

Aman, A. (2011). Model evaluasi pembelajaran sejarah. Yogyakarta: Ombak.

Amir, M. T. (2015). Inovasi pendidikan melalui problem based learning: Bagaimana pendidik memberdayakan pemelajar di era pendidikan. Jakarta: Kencana.

Anitah, S. (2009). Teknologi pendidikan. Solo: Inti Media Surakarta.

Anitah, S. (2010). Media pembelajaran. Solo: UNS Press.

Arsyad, A. (2010). Media pembelajaran. Jakarta: PT. Raja Grafindo Persada.

Daryanto. (2013). Menyusun modul (Baban ajar untuk persiapan guru dalam mengajar). Yogyakarta: Gava Media.

Gredler, M. E. (2011). Learning and instruction Teori dan aplikasi. (Tri Wibowo B. S., Trans.). Jakarta: Kencana Prenada Media Group.

Huda, M. (2014). Model-model pembelajaran dan pengajaran isu-isu metodis dan paradigmatis. Yogyakarta: Pustaka Pelajar.

Humaedi, M. A. (2014). Kegagalan akulturasi budaya dan isu agama dalam konflik Lampung. Analisa, 21(2), 149-162. https://doi.org/10.18784/analisa.v21i0 2.11

Illeris, K. (2011). Contemporary theories of learning: Teori-teori pembelajaran kontemporer. Bandung: Nusa Media.

Kochhar, S. K. (2008). Pembelajaran sejarah (Teaching of history). Jakarta: PT. Gramedia Widiasarana Indonesia.

Lampung Province's Daily Council - Batch 45. (1995). Sejarah perkembangan pemerintahan di Lampung (Book II). Bandar Lampung: Badan Penggerak Pembina Potens iAngkatan 45.

Lunenburg, F. C. (2011). Critical thinking and constructivism techniques for improving student achievement. 
National Forum of Teacher Education Journal, 21(3), 1-9.

Masek, A., \& Yamin, S. (2011). The effect of problem based learning on critical thinking ability: A theoretical and empirical review. International Review of Social Sciences and Humanities, 2(1), 215221.

Pribadi, B. A. (2014). Desain dan pengembangan program pelatihan berbasis kompetensi (Implementasi model ADDIE). Jakarta: Prenada Media Group.

Rezaee, A. A., \& Azizi, Z. (2012). The role of zone of proximal development in the students' learning of English adverbs. Journal of Language Teaching and Research, 3(1), 51-57. https://doi.org/ 10.4304/jltr.3.1.51-57

Rosyad, A. (2003). Teori belajar dan pembelajaran. Jakarta: PT. Rineka Cipta.

Sani, A. R. (2015). Pembelajaran saintifik untuk implementasi kurikulum 2013. Jakarta: Bumi Aksara.

Schunk, D. H. (2012). Learning theories: An educational perspective. (E. Hamidah \& R. Fajar, Trans.) (6th ed.). Yogyakarta: Pustaka Pelajar.

Slavin, R. E. (2011). Psikologi pendidikan: Teori dan praktik. (M. Samosir, Trans.). Jakarta: Indeks.

Styron, R. A. (2014). Critical thinking and collaboration: A strategy to enhance student learning. Journal of Systemics,
Cybernetics and Informatics, 12(7), 25-30.

Retrieved from http://www.iiisci.org/ journal/sci/FullText.asp?var=\&id=EI5 97JP12

Suarsana, I. M., \& Mahayukti, G. A. (2013). Pengembangan e-modul berorientasi pemecahan masalah untuk meningkatkan keterampilan berpikir kritis mahasiswa. Jurnal Pendidikan Indonesia, 2(2), 264-275. Retrieved from https:// journal.undiksha.ac.id/index.p $\mathrm{hp} / \mathrm{JPI} /$ article/view/2171/1887

Supriatna, N. (2011). Konstruksi pembelajaran sejarah yang berorentasi pada masalah kontemporer pembangunan. MIMBAR: Jurnal Sosial Dan Pembangunan, 27(1), 21-30. https:// doi.org/10.29313/mimbar.v27i1.308

Suranto. (2015). Teori belajar \& pembelajaran kontemporer. Yogyakarta: LaksBang PRESSindo.

Sutimin, L. A., \& Wahyuni, S. (2013). Perencanaan pembelajaran sejarah. Yogyakarta: Ombak.

Ward, J. D., \& Lee, C. L. (2002). A review of problem-based learning. Journal of Family and Consumer Sciences Education, 20(1), 16-26.

Wasino, W. (2005). Sejarah lokal dan pengajaran sejarah di sekolah. Jurnal Paramita, 15(1). 